P-ISSN: 2615-1723

E-ISSN: 2615-1766

Oktober 2019
Jurnal Riset Pendidikan Dasar

02 (2), (2019) 122-129

Submitted: Juli, Accepted Agustus, Published: Oktober

\title{
PENINGKATAN SIKAP KERJASAMA DAN PRESTASI BELAJAR SISWA MELALUI PEMBELAJARAN SOSIODRAMA BERBASIS “ATONG" PADA TEMA 8 DI KELAS IV SD N 1 LIMPAKUWUS
}

\author{
Aji Heru Muslim*, \& Nikmah Setyaningsih \\ Prodi PGSD, FKIP Universitas Muhammadiyah Purwokerto, Indonesia \\ *Korespondensi. E-mail: ajiherumuslim@ump.ac.id
}

\begin{abstract}
Abstrak
Penelitian ini bertujuan untuk meningkatkan sikap kerjasama dan prestasi belajar siswa pada Tema 8 di kelas IV SD N 1 Limpakuwus dengan menggunakan pembelajaran Sosiodrama berbasis ATONG. Penelitian ini adalah Penelitian Tindakan Kelas yang terdiri dari 2 siklus dan pada setiap siklus terdiri dari 2 kali pertemuan, desain penelitian tindakan kelas ini menggunakan desain PTK Arikunto. Obyek penelitian ini yaitu siswa kelas IV yang berjumlah 30 anak yang terdiri dari 14 laki-laki dan 16 perempuan. Instrument yang digunakan dalam pengumpulan data meliputi instrument tes dan non tes. Instrument tes terdiri dari tes tertulis dalam bentuk uraian yang dilakukan pada setiap akhir pertemuan. Sedangkan instrument non tes terdiri dari observasi, wawancara dan dokumen. Analisis data yang digunakan terdiri dari analisis data kualitatif dan kuantitatif. Berdasarkan hasil penelitian, prestasi belajar siswa diperoleh ketuntasan klasikal pada Siklus I Pertemuan 1 dan 2 yaitu 50\% dan $63 \%$ dan pada siklus II pertemun 3 dan 4 diperoleh ketuntasan klasikal yaitu $83 \%$ dan $93 \%$. Sikap kerjasama siswa diperoleh skor pada siklus I yaitu 69 dengan kriteria baik dan pada siklus II diperoleh skor yaitu 88 dengan kriteria sangat baik. Berdasarkan hasil tersebut, kesimpulan dari penelitian ini yaitu adanya peningkatan sikap kerjasama dan prestasi belajar siswa menggunakan pembelajaran sosiodrama berbasis ATONG siswa kelas IV SD N 1 Limpakuwus.

Kata Kunci: Kerjasama, Prestasi belajar, Sosiodrama berbasis ATONG
\end{abstract}

\section{INCREASING STUDENT ATTITUDES AND STUDENT ACHIEVEMENTS THROUGH SOSIODRAMA LEARNING BASED ON "ATONG" AT 8 THEMES IN CLASS IV SD N 1 LIMPAKUWUS}

\begin{abstract}
This study aims to improve the attitude of cooperation and student achievement in Theme 8 in class IV of SD N 1 Limpakuwus by using ATONG-based Sociodrama learning. This type of research is Classroom Action Research which consists of 2 cycles and in each cycle consists of 2 meetings, the design of this class action research uses the Arikunto PTK design. The object of this research is class IV students, amounting to 30 children consisting of 14 men and 16 women. The instrument used in data collection includes test and non-test instruments. The test instrument consists of a written test in the form of a description carried out at the end of each meeting. While non-test instruments consist of observations, interviews and documents. Analysis of the data used consisted of analysis of qualitative and quantitative data. Based on the results of the study, student achievement was obtained in classical completeness in Cycle I Meeting 1 and 2 namely $50 \%$ and $63 \%$ and in the second and third cycles 3 and 4 the classical completeness was $83 \%$ and $93 \%$. The attitude of collaboration between students obtained a score in the first cycle, namely 69 with good criteria and in the second cycle obtained a score that is 88 with very good criteria. Based on these results, the conclusion of this study is that there is an increase in the attitude of cooperation and student achievement using ATONG-based sociodrama learning in fourth grade students of SD N 1 Limpakuwus.

Keywords: Cooperation, Learning Achievement, Sociodrama Based ATONG
\end{abstract}




\section{Jurnal Riset Pendidikan Dasar, 02 (2), Oktober 2019 (122-129)}

Aji Heru Muslim, \& Nikmah Setyaningsih

\section{PENDAHULUAN}

Kehadiran globalisasi pada era sekarang sudah tidak bisa terelakan lagi. Globalisasi dikenal sebagai sebuah proses mendunia tanpa batas, munculnya berbagai unsur-unsur baru seperti pengaruh kebudayaan, perilaku, dan gaya hidup yang diikuti dengan perkembangan teknologi dan informasi yang semakin pesat. Kebijakan yang dilakukan oleh pemerintah Indonesia untuk mengantisipasi perkembangan globalisasi dan teknologi informasi komunikasi yang semakin pesat yaitu melalui sebuah jalur yang disebut pendidikan. Menurut UU Sisdiknas nomor 20 tahun 2003 menjelaskan bahwa Pendidikan adalah usaha sadar dan terencana untuk mewujudkan suasana belajar dan proses pembelajaran agar siswa secara aktif mengembangkan potensi dirinya untuk memiliki kekuatan spiritual keagamaan, pengendalian diri, kepribadian, kecerdasan, ahlak mulia, serta keterampilan yang dimiliki untuk dirinya dan masyarakat.

Wujud implementasi adanya pendidikan di Indonesia yaitu melalui sebuah lembaga formal yang disebut sekolah. Sekolah sebagai wahana untuk mengembangkan kognitif, afektif, dan psikomotorik siswa. Sekolah diharapkan mampu mengembangkan dan mewujudkan jiwa positif bagi siswa, salah satu upaya yang dilakukan yaitu dengan penanaman sikap kerjasama siswa. Oleh karena itu penanaman pendidikan karakter seperti sikap kerjasama yang ada di Indonesia idealnya diberikan mulai dari pendidikan dasar hingga perguruan tinggi sebagai upaya untuk mencegah kelunturan nilai-nilai kerjasama.

Siswa-siswi pada zaman sekarang ini sudah terpengaruhi oleh berbagai pengetahuan-pengetahuan yang bersifat negatif seperti pengaruh budaya asing, perkembangan teknologi dan komunikasi dan adanya sinetron-sinetron ditelevisi yang di dalamnya terdapat latar sekolah dan siswanya membentuk sebuah geng yang Copyright (C2019, JRPD, ISSN 2615 - 1723 (Print), ISSN 2615 - 1766 (Online) membeda-bedakan antara kelompok satu dengan lainnya hal ini diutarakan oleh guru kelas IV SD N 1 Limpakuwus. Pengaruh seperti itulah yang diaplikasikan dalam proses pembelajaran khususnya di kelas IV, siswasiswinya sudah menerapkan sistem geng kelompok yang membeda-bedakan kelompok satu dengan yang lainnya, dan pada saat guru menggunakan metode belajar berkelompok siswa sulit untuk menjalin kerjasama dengan baik karena cenderung bekerja sendiri-sendiri, sehingga proses pembelajaran yang sudah direncanakan tidak berjalan dengan maksimal.

Guru kelas IV SD N 1 Limpakuwus juga mengatakan bahwa sebagus dan semenarik apapun pendekatan yang digunakan dalam proses pembelajaran ketika menggunakan sistem kelompok para siswa siswinya susah untuk diatur siswa cenderung untuk memilih berkelompok dengan kelompok gengnya masing-masing, dari segi itulah pembelajaran yang berlangsung sangat tidak kondusif karena sikap kerjasama yang terjalin di kelas sangat sulit untuk ditumbuhkan. Permasalahan lain yang dirasakan oleh Guru kelas IV SD N 1 yaitu bahwa pembelajaran yang dilaksanakan masih menggunakan sistem pembelajaran seperti biasa, karena kondisi siswa yang susah untuk diatur sehingga metode, dan strategi yang digunakan juga berjalan biasa seperti ceramah, penugasan, dan teks book.

Permasalahan lain yang terjadi di kelas IV SD N 1 Limpakuwus yaitu tidak hanya pada sikap kerjasama saja melainkan juga pada prestasi belajar yang dimiliki oleh siswa sangat rendah, rata-rata nilai siswa masih dibawah KKM, hal ini dapat terlihat dari data nilai ulangan harian dan ulangan tengah semester I pada tahun ajaran 2018/2019 yang terdapat pada tabel 1 dibawah ini: 
Jurnal Riset Pendidikan Dasar, 02 (2), Oktober 2019 (106-115)

Aji Heru Muslim, \& Nikmah Setyaningsih

Tabel 1 Data Nilai UH Dan UTS Tahun Pelajaran 2018/2019

\begin{tabular}{|c|c|c|c|}
\hline No & Nilai Rata-rata & KKM & Keterangan \\
\hline 1 & 63 & 70 & UH \\
\hline 2 & 67 & 70 & UTS \\
\hline
\end{tabular}

ATONG menurut (Muslim:2016) yaitu A:

Berdasarkan tebel 1 di atas guru kelas bersama peneliti menyepakati untuk meningkatkan sikap kerjasama dan prestasi belajar siswa. Siswa juga mengungkapkan bahwa proses pembelajaran yang diikuti terlalu menekankan kepada materi dan penjelasan guru, siswa jarang untuk terlibat secara langsung dalam proses pembelajaran yang menyebabkan siswa bosan dalam proses pembelajaran. Kebosanan siswa dalam mengikuti pembelajaran mengakibatkan konsentrasi, minat, dan siswa menjadi pasif yang mengakibatkan pembelajaran menjadi tidak efektif. Kondisi pembelajaran yang hanya menggunakan metode ceramah, menyebabkan siswa tidak terlibat langsung dalam kegiatan belajar mengajar, dan kurangnya penanaman sikap persatuan menjadikan pembelajaran selama ini kurang efektif karena tujuan pembelajaran tidak dapat tercapai.

Guru menyadari bahwa kondisi seperti ini tidak dapat dibiarkan begitu saja, karena dapat menimbulkan permasalahan yang lebih besar. Peneliti dan guru merasa perlu melakukan upaya perbaikan terhadap kondisi tersebut. Disepakati bahwa peneliti dan guru akan bekerjasama melaksanakan Penelitian Tindakkan Kelas (PTK) di kelas IV pada "Tema 8 Daerah Tempat Tinggalku" menggunakan Pembelajaran Sosiodrama berbasis ATONG untuk meningkatkan sikap kerjasama dan prestasi belajar siswa.

Sosiodrama digunakan peneliti dalam menyelesaikan masalah karena memiliki keunggulan yaitu dapat membawa siswa pada suasana secara langsung karena mereka berperan sebagai orang lain, mendramatisasi agar peserta didik berperan langsung dalam proses pembelajaran sehingga akan memberikan sebuah pembelajaran yang bermakna dan dilengkapi dengan penerapan Amati (terhadap semua situasi belajar) $\mathrm{T}$ : Tanya (pada setiap masalah yang muncul) $\mathrm{O}$ : Olah (atas jawaban dari pertanyaan) N: Nalar (untuk meneruskan sampai pada) G: Gagas (suatu ide atau inovasi baru). Pembelajaran dengan menggunakan berbasis ATONG, lebih menekankan kepada aktivitas dan keaktifan peserta didik, sehingga guru hanya berperan sebagai fasilitator dalam proses pembelajaran.

Berdasarkan latar belakang di atas yang seperti peneliti telah jelaskan, maka rumusan masalah pada penelitian ini yaitu "Bagaimana peningkatan sikap kerjasama, dan prestasi belajar siswa pada tema 8 kelas IV SD $\mathrm{N} 1$ Limpakuwus dengan menerapkan pembelajaran sosiodrama berbasis ATONG?"

\section{METODE}

Subyek penelitian ini adalah siswa kelas IV Sekolah Dasar N 1 Limpakuwus Kecamatan Sumbang Kabupaten Banyumas dengan jumlah siswa 30 yang terdiri dari 14 siswa laki-laki dan 16 siswi perempuan. Untuk memperoleh data dalam Penelitian diperlukan teknik pengumpulan data. Teknik yang digunakan adalah teknik tes dan non tes. Teknik Tes dalam penelitian ini berupa soalsoal yang digunakan untuk mengukur prestasi belajar siswa. Arifin (2011:118) mengemukaan teknik tes merupakan cara pengukuran dalam bentuk pertanyaan-pertanyaan yang dikerjakan siswa untuk mengukur aspek prestasi siswa. Sedangkan teknik nontes digunakan dalam penelitian ini berupa lembar obaservasi untuk mengukur sikap kerjasama siswa. Kusnandar (2008:143) mengemukan bahwa observasi merupaka kegiatan pengambilan data dengan cara memotret atau pengamatan secara langsung.

Analisis data yang digunakan dalam penelitian ini meliputi analisis tes dan analisis Copyright (C2019, JRPD, ISSN 2615 - 1723 (Print), ISSN 2615 - 1766 (Online) 
sikap kerjasama. Untuk menganalisis data prestasi belajar menggunakan cara sebagai berikut:

$\mathrm{P}=\frac{F}{N}$

Keterangan:

$\mathrm{P}:$ Persentase ketuntasan hasil belajar

$\mathrm{F}$ : Jumlah siswa yang tuntas belajar

$\mathrm{N}$ : Jumlah seluruh siswa

(Djamarah, 2010: 264)

Analisis yang digunakna untuk mengethaui sikap kerjasama dilakukan dengan cara sebagai berikut:

$\mathrm{NP}=\frac{R}{S M} \times 100$

Keterangan:

$\mathrm{NP}=$ Nilai yang dicari atau diharapkan

$\mathrm{R}=$ Skor mentah yang diperoleh siswa

$\mathrm{SM}=$ Skor maksimum

$100=$ Bilangan tetap

(Purwanto, 2010: 102)

Penelitian ini dilaksanakan dalam dua siklus dan menggunakan model PTK menurut Arikunto, dkk (2010:16) yang mepunyai 4 tahapan yaitu a) tahap perencanaan (Planing),

b) Pelaksanaan tindakan (Acting), c) Pengamatan (Observing), d) Refleksi (Reflecting). Penelitian ini dikatakan berhasil apabila adanya peningkatan prestasi belajar siswa dengan menggunakan pembelajaran Sosiodrama berbasis ATONG sekurangkurangnya $75 \%$ (minimal dalam katagori Baik) dari jumlah siswa yang telah mencapai KKM yaitu 70. Adanya peningkatan sikap kerjasama yang dilakukan siswa kelas mencapai $75 \%$ (minimal dalam kategori baik) dengan menggunakan pembelajaran sosiodrama berbasis ATONG dalam katagori Baik.

\section{HASIL DAN PEMBAHASAN}

Setelah dilakukan Penelitian Tindakan Kelas menggunakan pembelajaran sosiodrama berbasis ATONG yang dilaksankakan sejumlah dua siklus yang terdiri dari empat kali pertemuan, maka dapat diperoleh hasil sebagai berikut:

1. Prestasi Belajar Siswa

Perolehan prestasi belajar siswa dapat ditunjukan dalam gambar 1 berikut ini:

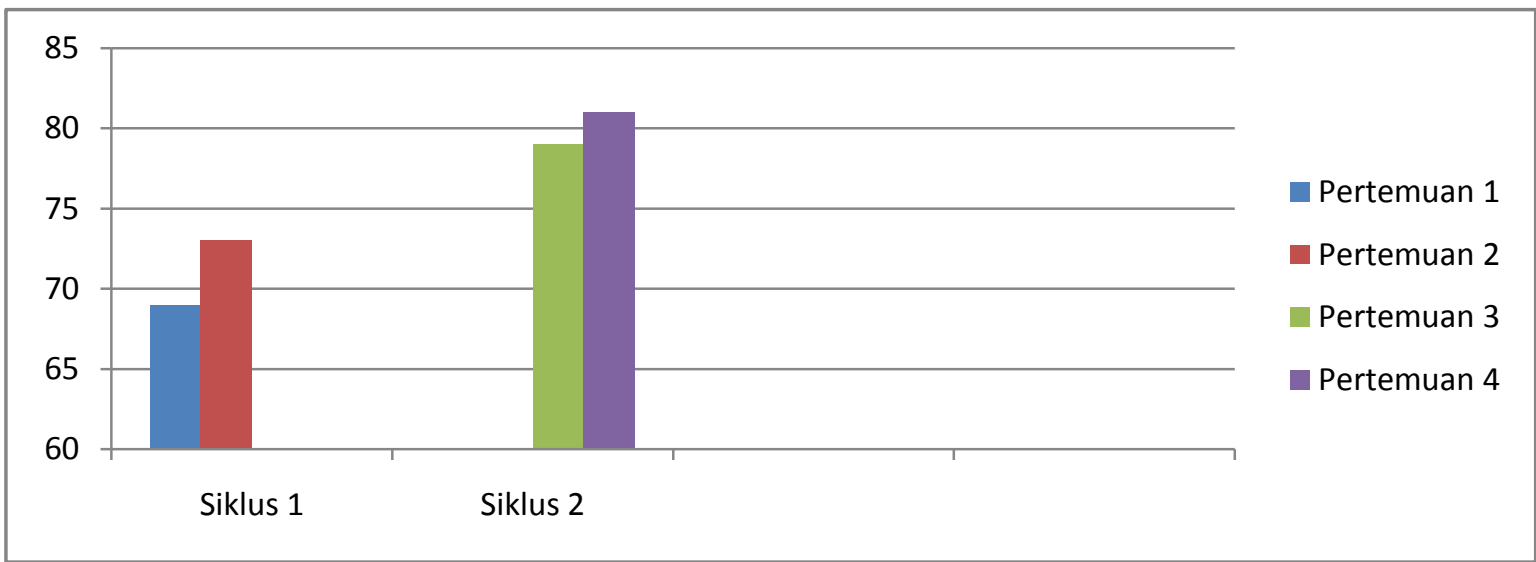

Gambar 1 Diagram Pencapaian Prestasi belajar Siswa

Gambar 1 menunjukkan pencapaian prestasi belajar siswa yang diperoleh dari hasil tes evaluasi siswa pada setiap siklus. Prestasi belajar siswa pada siklus I Pertemuan 1 dan 2 masih kurang. Hal tersebut ditunjukkan pada pertemuan 1 terdapat 15 siswa belum tuntas
23 (Print), ISSN $2615-1766$ (Online) 


\section{Jurnal Riset Pendidikan Dasar, 02 (2), Oktober 2019 (122-129)}

\section{Aji Heru Muslim, \& Nikmah Setyaningsih}

dari 30 siswa pada pertemuan 2 terdapat 11 siswa yang belum tuntas dari 30 siswa, sedangkan siswa yang tuntas pada pertemuan 1 sejumlah 15 siswa dan pada pertemuan 2 sejumlah 19 siswa. Nilai rata-rata kelas pada siklus I Pertemuuan 1 yaitu 69 belum memenuhi KKM yaitu 70 pada Tema 8 dan pada siklus I Pertemuan 2 yaitu 71 sudah memenuhi KKM yaitu 70 namun siswa yang belum tuntas masih banyak sehingga harus diperbaiki pada siklus berikutnya. Perolehan ketuntasan klasikal pada siklus I Pertemuan 1 yaitu $50 \%$ dan Siklus I Pertemuan 2 yaitu $63 \%$ juga belum memenuhi indikator keberhasilan.

Pada siklus II pencapaian hasil belajar ranah kognitif siswa mengalami peningkatan yaitu dengan jumlah siswa yang tuntas pada pertemuan 1 yaitu 25 dan pada pertemuan 2 yaitu 28 siswa dan siswa yang tidak tuntas pada pertemuan 1 yaitu 5 siswa dan pada pertemuan 2 yaitu 2 siswa. Nilai rata-rata kelas yang diperoleh pada pertemuan 1 yaitu 79 dan pada pertemuan 2 yaitu 81 sudah memenuhi KKM yang ditentukan yaitu 70 sedangkan ketuntasan klasikal pada siklus II pertemuan 1 yaitu $83 \%$ dan pada pertemuan 2 yaitu $93 \%$ telah memenuhi indikator pencapaian ketuntasan yaitu sekurang-kurangnya $75 \%$ dari nilai KKM 70.

Peningkatan prestasi belajar siswa juga dipengaruhi oleh aktivitas guru dalam melaksanakan kegiatan pembelajaran. Hal ini ditunjukan bahwa guru selalu berupaya untuk meningkatkan kinerja dalam mengajar agar setiap indikator dalam pembelajaran sosiodrama berbasis ATONG dapat dilakukan dan tercapai dengan baik. Peningkatan tersebut karena guru telah memahami RPP dan dapat mengkondisikan siswa pada saat pembelajaran. $\mathrm{Hal}$ tersebut selaras dengan hasil wawancara dengan Guru bahwa menurut beliau selama sikus I sampi siklus II sudah mulai terbiasa dengan pembelajaran yang digunakan dan dapat mengkondisikan siswa saat pembeajaran dengan baik, beliau juga megakui bahwa penerapan pembelajaran sosiodrama berbasis ATONG di siklus I kurang maksimal karena Copyright $@ 2019$, JRPD, ISSN 2615 - beliau merasa baru beradaptasi dengan penerapan pembelajaran tersebut.

Kekurangan di siklus I dijadikan sebagai tolak ukur untuk selalu belajar sehingga pada penerapan di siklus II sudah maksimal dan siswa dapat melakukan pembelajaran dengan lebih baik. Siklus I mencapai nilai rata-rata 68 dengan kriteria baik. Nilai rarta-rata tersebut diperoleh karena guru kurang masih kurang menguasai pembelajaran sosiodrama berbasis ATONG sehingga perlu ditingkatkan pada siklus II. Guru menyadari bahwa dalam pelaksanaan menggunakan pembelajran sosiodrama berbais ATONG masih kurang baik maka guru berusaha meningkatkan dan berusaha mempelajari pembelajaran. Guru selalu berupaya untuk memperbaiki setiap indikator yang masih kurang baik sehingga aktivitas guru selalu meningkat pada setiap siklus. Peningkatan aktivitas guru dalam proses pembelajaran sangat mempengaruhi terhadap kualitas pembelajaran sehingga prestasi belajar siswa meningkat.

Perolehan hasil prestasi belajar siswa yang meningkat dari setiap pertemuan pada siklus I ke siklus II menunjukkan bahwa penggunaan pembelajaran sosiodrama berbais ATONG di kelas IV SD N 1 Limpakuwus dapat meningkatkan prestasi belajar siswa pada materi tema 8. Melalui penerapan pembelajaran sosiodrama berbasis ATONG guru menjadi lebih kreatif dalam mengajar, dan siswa menjadi lebih aktif dan paham tentang materi yang diberikan guru sehingga prestasi belajar siswa meningkat dari siklus I ke siklus II selaras dengan Muslim (2016) yang menjelaskan bahwa strategi ATONG merupakan strategi pembelajaran yang digunakan untuk meningkatkan proses pembelajaran menjadi lebih aktif dalam proses pembelajaran. Berdasarkan pendapat tersebut disimpulkan bahwa pembelajaran sosiodrama berbais ATONG menjadikan suasana pembelajaran menjadi lebih aktif dan terjalinya kerjasama dalam proses pembelajaran.

Hasil yang diperoleh oleh siswa tersebut dapat meningkat dikarenakan upaya guru 723 (Print), ISSN 2615 - 1766 (Online) 


\section{Jurnal Riset Pendidikan Dasar, 02 (2), Oktober 2019 (122-129)}

Aji Heru Muslim, \& Nikmah Setyaningsih

menggunakan pembelajaran sosiodrama berbasis ATONG. Dalam pembelajaran sosiodrama berbasis ATONG siswa belajar untuk menemukan sendiri sesuatu yang dianggap baik kemudian dipilih dan ditanamkan dalam diri siswa sendiri. Pada saat sosiodrama guru membuat tema yang berkaitan dengan materi tema 8. Materi tersebut tersirat dalam tema yang kemudian diperankan oleh siswa. Dengan menggunakan pembelajaran sosiodrama berbasis ATONG pembelajaran yang berlangsung lebih bermakna karena siswa aktif. Siswa melakukan proses mengamati, menanyakan, mengolah, menalar, dan menggagas dari apa yang telah mereka dapatkan dalam proses pembelajaran melalui penerapan berbasis ATONG.
Penerapan pembelajaran sosiodrama memberikan keempatan kepada siswa untuk berekspresi, beraktivitas, dan mengingat seperti yang dijelaskan oleh Said (2015:269) bahwa Sosiodrama adalah metode holistik yang menggabungkan kemampuan mengingat, berekspresi, beraktivitas, dan makna sebuah peran dan jalan cerita. Maksudnya yaitu pembelajaran sosiodrama juga sebagai salah satu alternatif pembelajaran yang memudahkan siswa untuk memahami materi pembelajaran.

2. Sikap Kerjasama Siswa

Sikap kerjasama pada setiap siklus I dan II mengalami peningkatan. Perolehan sikap kerjasama siswa dapat ditunjukan dalam gambar 2 berikut ini:

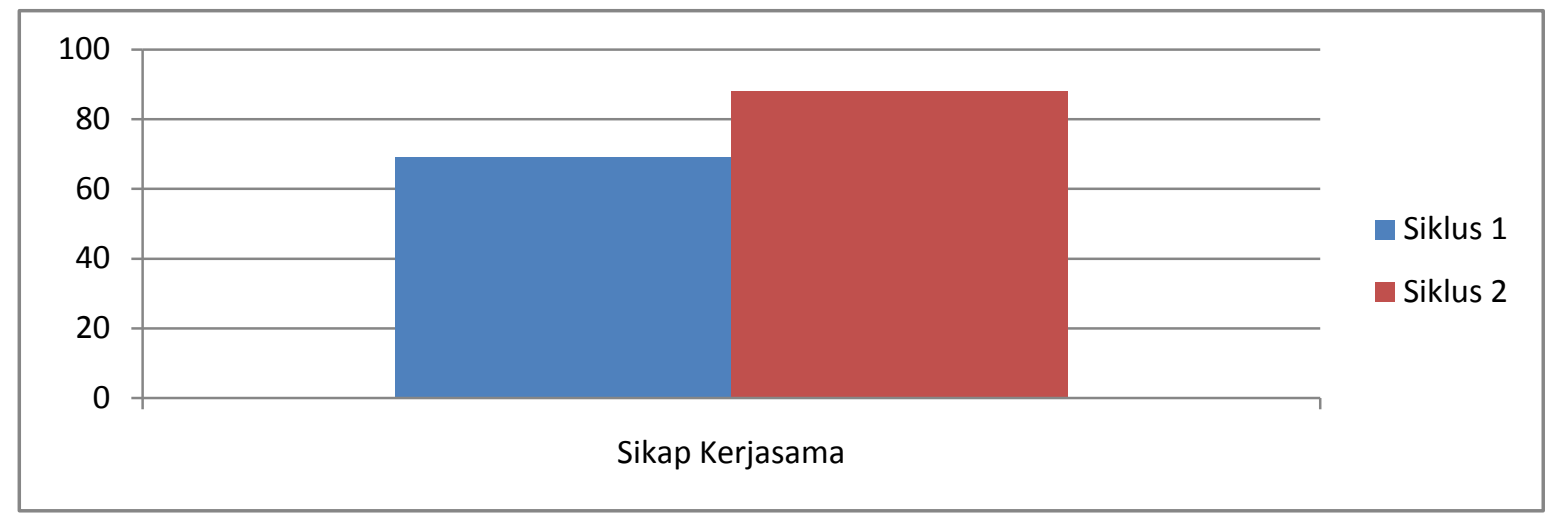

Gambar 2. Diagram Peningkatan Sikap Kerjasama Siswa

Gambar 2 menunjukkan pencapaian sikap kerjasama siswa yang meningkat pada tiap siklus. Pada siklus I, perolehan skor sebesar 69 dengan kriteria keterampilan kerjasama baik, dan pada siklus II perolehan skor sebesar 88 dengan kriteria keterampilan kerjasama sangat baik. Peningkatan sikap kerjasama siswa juga dipengaruhi oleh aktivitas siswa dalam mengikuti kegiatan pembelajaran. Hal ini menunjukkan bahwa siswa selalu berupaya untuk meningkatkan aktivitas belajarnya agar setiap indikator aktivitas dapat tercapai dengan sangat baik.

Penigkatan tersebut dikarenakan siswa telah dapat mengikuti pembelajaran dengan baik dan mereka sangat antusias pada saat mengikuti pembelajaran. Hal tersebut selaras dengan hasil wawancara dengan beberapa siswa kelas IV SD N 1 Limpakuwus bahwa mereka mengakui pembelajaan yang diikutinya baru pertama kali dilakukan sehigga mereka merasa lebih mudah untuk menjalin kerjasama dengan teman satu kelasnya dan dapat memahami materi yang diberikan oleh guru. Siswa telah mengikuti pembelajaran dengan sangat baik yang ditunjukkan dengan adanya sikap dalam belajar yang baik dan tertib pada saat pembagian kelompok, bersikap baik saat sosiodrama, saling bekerjasama ketika melakukan pembelajaran sosiodrama berbasis ATONG. Muslim (2016:04) mengatakan 


\section{Jurnal Riset Pendidikan Dasar, 02 (2), Oktober 2019 (122-129)}

Aji Heru Muslim, \& Nikmah Setyaningsih

bahwa pembelajaran dengan menggunakan ATONG lebih memfokuskan pada aktivitas siswa karena siswa dilibatkan pada keterampilan proses sehingga proses pembelajaran yang berlangsung dapat menjadikan aktivitas siswa lebih aktif. Guru memberikan kebebasan ketika siswa melakukan sosiodrama berbasis ATONG sehingga siswa tidak perlu merasa bahwa dirinya salah ketika melakukan sosiodrama.

Dalam melakukan sosiodrama, cerita atau tema yang dibuat oleh guru disesuaikan dengan yang ada dalam kehidupan nyata atau kehidupan sehari-hari siswa seperti hubungan sosial antar manusia, seperti yang dikemukakan Rostiyah (2008:90) mengatakan bahwa Sosiodrama adalah siswa dapat mendramatisasikan tingkah laku, atau ungkapan gerak- gerik wajah seseorang dalam hubungan sosial antar manusia. Adanya peningkatan sikap kerjasama siswa dari siklus I ke siklus II membuktikan bahwa ketrampilan kerjasama siswa dapat ditanamkan menggunakan pembelajaran sosiodrama berbasis ATONG. Pernyataan tersebut memberikan penjelasan bahwa pembelajaran dengan sosiodrama berbasis ATONG mengajarkan siswa untuk saling bekerjasama, hal tersebut dibuktikan pada saat guru membagi kelompok belajar untuk melaksanakan kegiatan, setelah guru membagikan naskah sosiodrama kepada masing-masing kelompok siswa yang telah terpilih dengan kelompoknya menunjukan terjalinnya kerjasama dengan membagi pemeranan di dalam kelompoknya, selain itu pada saat sebelum pelaksanaan pemeranan kelompok yang sudah terpilih saling bekerjasama membantu memakai kostum, memakai mahkota nama sesuai dengan tema cerita yang mereka perankan.

Adanya peningkatan keterampilan kerjasama siswa juga didorong dengan pembelajaran sosiodrama berbasis ATONG merupak bentuk strategi yang didalamnya mengandung proses sehingga siswa lebih aktif dalam pembelajaran dibandingkan dengan guru, dalam proses pembelajaran dengan penerapan pembelajaran ATONG guru hanya bertindak sebagai fasilitator. Proses pembelajaran dengan menggunakan pembelajaran sosiodrama berabsis ATONG memberikan peran penting dalam proses pembelajaran sosiodrama, karena dengan adanya berbasis ATONG mengajarkan siswa agar saling bekerjasama memecahkan sebuah permasalahan yang terdapat dalam kegiatan sosiodrama yang telah dilakukan sehingga memunculkan pengolahan informasi melalui sebuah diskusi kelompok yang tanpa disadari penanaman keterampilan kerjasama sedang dilakukan. Hal tersebut selaras dengan pendapat Muslim (2016) yang menjelaskan bahwa strategi ATONG merupakan strategi pembelajaran yang digunakan untuk meningkatkan proses pembelajaran menjadi lebih aktif dan terjalinya kerjasama dalam proses pembelajaran. Berdasarkan pernyataan tersebut memberikan peenguatan bahwa strategi ATONG dapat meningkatkan kerjasama siswa seperti yang terjadi di kelas IV SD N 1 Limpakuwus yang telah menunjukan peningkatan keterampilan kerjasama mulai dari Siklus I sampai Siklus II

\section{SIMPULAN}

Berdasarkan penelitian tindakan kelas yang telah dilaksanakan maka dapat simpulan pembelajaran sosiodrama berbasis ATONG dapat meningkatkan prestasi belajar. $\mathrm{Hal}$ tersebut dapat ditunjukkan dengan adanya peningkatan prestasi belajar setiap pertemuan siklus I ke siklus II. Rata-rata siklus I pada setiap pertemuan yaitu pertemuan 1 yaitu 69 , pertemuan 2 yaitu 73 dengan ketuntasan klasikal 50\% dan 63\%. Rata-rata skor siklus II pada setiap pertemuan yaitu pertemuan 1 yaitu 79 , pertemuan 2 yaitu 81 dengan ketuntasan klasikal $83 \%$ dan 93\%. Selain meningkatkan prestasi belaja siswa pembelajaran sosiodrama berbasis ATONG dapat meningkatkan sikap kerjasama. Hal ini dapat ditunjukan pada siklus I diperoleh nilai rata-rata 69 dengan Copyright (C2019, JRPD, ISSN 2615 - 1723 (Print), ISSN 2615 - 1766 (Online) 
kriteria baik, sedangkan pada siklus II sikap kerjasama siswa mengalami peningkatan dengan skor rata-rata sebesar 86 dengan kriteria sangat baik.

Setelah melaksanakan penelitian tindakan kelas di SD N 1 Limpakuwus, peneliti mengajukan beberapa saran dalam melaksanakan pembelajaran menggunakan pembelajaran sosiodrama berbasis ATONG, yaitu sebagai berikut; a) Tema yang digunakan untuk sosiodrama hendaknya dibuat semenarik mungkin sehingga siswa lebih tertarik untuk memerankannya. Dengan tema yang menarik, maka siswa lebih bersemangat untuk maju ke depan melakukan sosiodrama; b). Penyususnan skenario sosiodrama disesuaikan dengan kemampuan siswa, diusahakana tidak terlalu panjang sehingga mudah dipahami oleh siswa; c) Penerapan berbasis ATONG, guru harus dapat memposisikan siswa pada pertanyaan tingkat tinggi sehingga kegiatan diskusi dapat brjalan dengana lebih makimal.

\section{DAFTAR PUSTAKA}

Arifin, Z. (2011). Evaluasi Pembelajaran. Bandung: PT Remaja Rosdakarya.

Arikunto Suharsimi, Suhardjono dan Supardi. (2010). Penelitian Tindakan Kelas. Jakarta : Bumi Aksara.

Djamarah, S.B. (2010). Guru dan Anak Didik dalam Interaksi Edukatif Suatu Pendekatan Teoritis Psikologis.Jakarta.PT Rineka Cipta.

Kunandar. (2008). Langkah Mudah Penelitian Tindakan Kelas Sebagai Pengembangan Profesi Guru. Jakarta : PT Rajagrafindo Persada.

Muslim, H, A dan Supriatna. (2016). Pengembangan perangkat pembelajaran PKn Model Cooperative tope TGT Berbasis ATONG Bagi Siswa ekolah Dasar. UM Purwokerto: Jurnal Pendidikan sekolah Dasar Vol.12, No 2 Juli 2016. [Online] Tersedia Copyright (C2019, JRPD, ISSN 2615 - 1723 (Print), ISSN 2615 - 1766 (Online)
http://journal.uad.ac.id/index.php/JPSD /article/view/5474 Diikses tanggal 24 April 2018 Pukul 17.24

Purwanto, Ngalim. (2010). Prinsip-prinsip dan Teknik Evaluasi Pengajaran. Bandung : Remaja Rosdakarya.

Rostiyah. (2008). Strategi Belajar Mengajar. Jakarta: PT Rineka Cipta

Said, A dan B, Andi. (2015). 95 Strategi Mengajar Multiple Intelligences Mengajar sesuai kerja otak dan gaya belajar siswa. Jakarta: Prenadamedia Group 